\title{
鳥取県における公立中学校の創設と昭和の町村合併による統廃合 PUBLIC JUNIOR HIGH SCHOOL FOUNDATION AND REORGANIZAITION BY MUNICIPAL MERGER IN THE SHOWA PERIOD IN TOTTORI PREFECTURE
}

\author{
細田智久*, 中園眞人**, 三谷亮太吕, 牛島 朗***, 下倉玲子***** \\ Tomohisa HOSODA, Mahito NAKAZONO, Ryota MITANI, \\ Akira USHIJIMA and Reiko SHIMOKURA
}

\begin{abstract}
This paper aims to analyze the reorganization process of public junior high schools in Tottori Prefecture in the Chugoku region. After World War II, new junior high schools were established in many municipalities by the reform of the school education system. But many of these were consolidated as the great Showa mergers period took place in the middle of 1950s. The Tottori Prefectural Board of Education encouraged shared schools with a couple of municipalities in order to maintain ideal school size that was more than 600 students per school. A consolidation of junior high schools was nearly completed in the early stages of the 1970s, no major changes in school numbers have been seen in the following years.
\end{abstract}

Keywords:Public J unior High School, School F oundation, M erger of Town and Village, Amalgamation and Reorganization, Tottori Prefecture 公立中学校, 学校創設, 町村合併, 統廃合, 鳥取県

\section{1. 序論}

1947 年の学校教育法制定により中学校教育が義務化されたが、 当初は既存施設の借上げや転用により校舎を確保せざるを得ない状 況であった。1953 年には「町村合併促進法注 1)」により小規模町村の 合併が進められ注2)、学校施設の再編が課題となった。1956 年の「新 市町村建設促進法注3)」により、学校の統廃合(以下、統合と略)時の 校舎建築に対する国庫補助率引上げとともに、中央教育審議会で学 校統合基準注4) が示され、1958 年の「義務教育諸学校施設費国庫負 担法」に組込まれる等 ${ }^{1)}$ ・注5)、政策として学校の統合が強力に進め られた。1960 年代の高度経済成長期以降、人口流出が著しい中国 地方の中山間地域や島嶼地域では、生徒数減少による中学校の統合 が進行した。さらに 1970 年の「過疎地域対策緊急措置法」により、 統合校舎建築の国庫補助率が引上げられ、小規模校統合が加速した。 1980 年代前半には第 2 次ベビーブームによる生徒数の回復があっ たが、その後は再び大幅な減少に転じ学校の小規模化が進行した。 その後、過疎地域の自治体は 2000 年以降合併により広域自治体を 形成した地域も多く、生徒数減少. 校舎の老朽化・耐震化の要請等に 伴う学校再編や建替え、あるいは廃校施設の維持管理と利活用が主 要課題となっている自治体が多い。

新制中学校は戦後旧自治体を基本単位として創設されたため、創
設期から昭和の町村合併期にかけて再編統合が強く迫られ、この期 間には小学校に比べて学校数減少の割合が高かった ${ }^{2)}$ ここのため、 中学校の推移は、戦後の創設と昭和の町村合併期 ( I 期)、経済成長 期の過疎地域での統合期 (II 期)、生徒数の増加期(III期)、平成の生徒 数減少と町村合併の以前・以後 $(\mathrm{IV} \cdot \mathrm{V}$ 期) の 5 区分が妥当と考える。

関連既往研究には、廃校の発生要因を分析した研究 ${ }^{3)}$ 、統合と廃 校舎の利活用決定プロセスの関連を考察した研究 ${ }^{4)} や 、$ 廃校のある 地域属性の特徵と再利用に関寸る研究 ${ }^{5)}$ 、廃校の施設利用に関して は公立小中学校施設の運用状沉に関する研究 ${ }^{6)}$ 等がある。また筆者 らは中国地方の公立中学校の 1960 年代以降の生徒・学校数推移の 動向を報告した ${ }^{7,8)}$ 。一方、新制中学校創設と昭和の町村合併は現 在の中学校の立地や規模に大きな影響を及ぼしているが、この時期 に視点を置き、自治体における学校施設の整備過程や町村合併によ る統合の経緯とその結果に関して考察した研究はみられない。 地方圈の中で鳥取県は中学校創設期に人口が少ない町村が多く 9) ・注 6)、生徒数確保のため原則複数町村による組合立主 7) を推奨し たが課題も山積し、創設直後から昭和の町村合併期にかけて急激な 再編統合が行われた。一方で、その後は統合が行われず安定的な中 学校運営を実現している。そこで本論では 1970 年代前半に中学校 再編が完了した鳥取県を対象に、(1)1947 年以降の新制中学校創設

\footnotetext{
* 米子工業高等専門学校 准教授·博士 (工学)

** 山口大学大学院創成科学研究科 教授.工博

*** 山口大学大学院理工学研究科 大学院生

**** 山口大学大学院創成科学研究科 助教 - 博士 (工学)

***** 呉工業高等専門学校 准教授·博士 (工学)

\author{
Assoc. Prof., National Institute of Technology, Yonago College, Dr. Eng. \\ Prof., Graduate School of Sciences and Tech. for Innovation, Yamaguchi Univ., Dr. Eng \\ Grad. Student, Graduate School of Science and Eng., Yamaguchi Univ. \\ Assist. Prof., Graduate School of Sciences and Tech. for Innovation, Yamaguchi Univ., Dr. Eng. \\ Assoc. Prof., National Institute of Technology, Kure College, Dr. Eng.
}




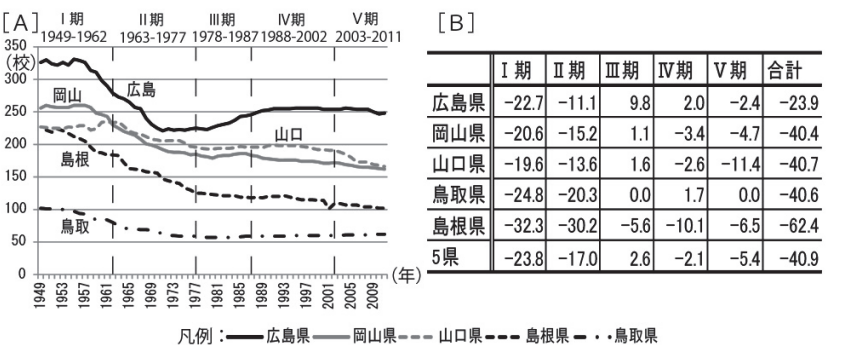

図 1 中国地方の [A] 中学校数推移 - [B] 各期中学校数増減率

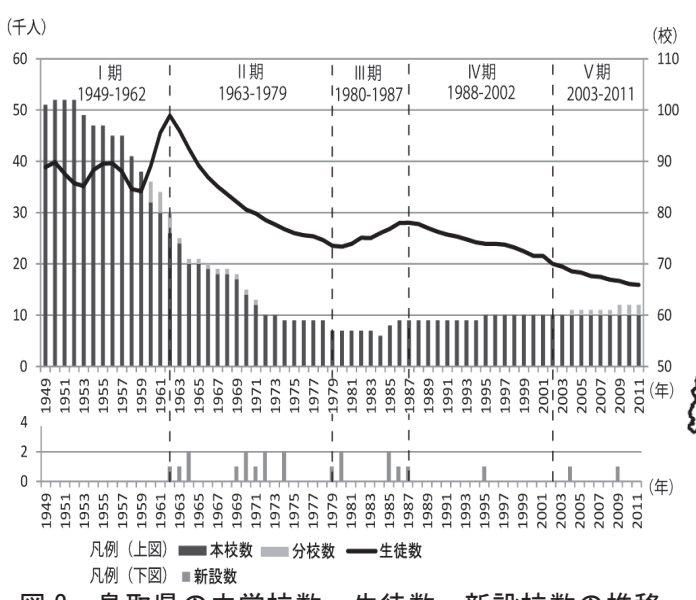

図 2 鳥取県の中学校数・生徒数・新設校数の推移

期の整備状況之直後の再編統合の経緯を解明し、さらに(2)各自治体 における 1953 年以降の町村合併と中学校統合との関係、(3)組合立 中学校の創設がその後の学校存続にもたらした影響を明らかにする ことを目的とする。得られた知見は、平成の合併を経て自治体がよ り広域化した今後の中学校再編を検討する上で有用と考える。

分析資料は鳥取県教育委員会所管学校基本調查(1960-2011)、鳥取 県教職員録(1949-1959）を基本とし、この他に各自治体の史誌、鳥 取県教育史、鳥取県町村合併誌、鳥取県中学校創立四十周年記念誌 等の文献資料 ${ }^{10)}$ を用いる。

2. 鳥取県の公立中学校の生徒·学校数の推移(1949 年から 2011 年) 2.1 中国地方における公立中学校の生徒 - 学校数の時期別推移

まず、中国地方 5 県における公立中学校の生徒数・学校数推移の 状沉を図 1 に示寸注 8$)$ 。左側に中学校数推移、右側に時期区分毎の 学校数増減率を示す注 9)。1949 年時点の創設数を見ると、鳥取県は 100 校程度で他 4 県の 200 校以上と比べ半数以下と少ない。

時期別に見ると、I 期(1949-1962)は昭和の町村合併により中学校 の統合が多く行われ、山口県以外の 4 県の学校数増減率は- $20 \%$ を 越え、特に島根県は- $32.3 \%$ と大きい注 10$)$ 。鳥取県は島根県に次ぐ24.8\%で、高い割合で廃校が生じている。II 期(1963-1977)になると 1973 年に「公立小・中学校の統廃合について」が文部省から通達され、 統合が減少傾向に転じた。 5 県とも I 期に比べ減少率は小さいが、 島根・鳥取県では II 期も-20\%以上を示す。III期(1978-1987)には減少 傾向にあった増減率が広島・岡山・山口県で増加に転じているものの、 鳥取県は II 期後半から学校数は変化していない。IV期(1988-2002) は学校数の変動は少ないが、広島・鳥取県のみ学校数が増加してい る 注 11)。V 期(2003-2011)になると平成の町村合併が行われ、中学校 の再編が行われていることから学校数は減少傾向を示す。ただし鳥

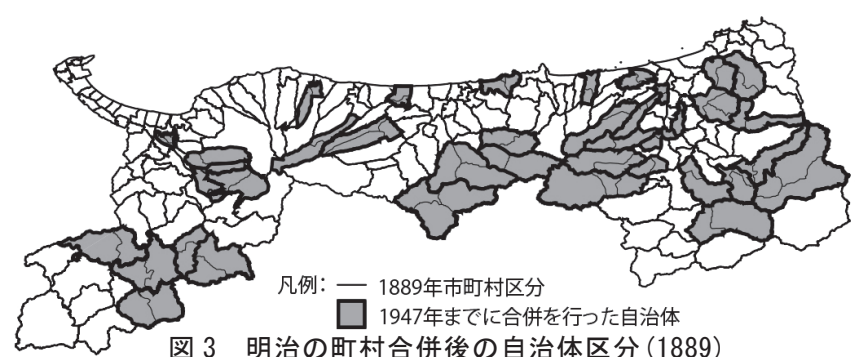

図 3 明治の町村合併後の自治体区分 (1889) 


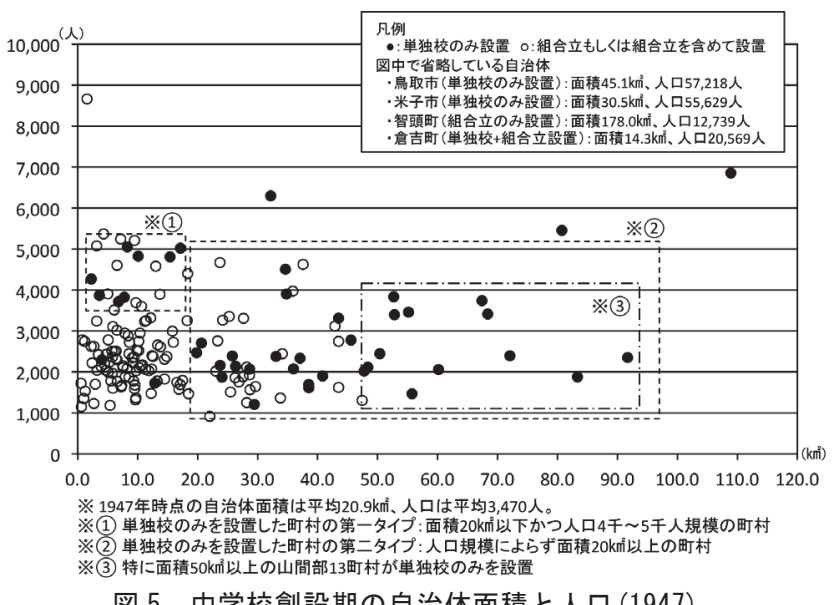

図 5 中学校創設期の自治体面積と人口 (1947) 表 1 創設期の自治体別学校数

\begin{tabular}{|c|c|r|r|r|r|r|r|}
\hline \multirow{4}{*}{} & 設立に参加 & \multicolumn{3}{c|}{ 設立学校数 } & \multicolumn{2}{|c|}{ 小計 } \\
\cline { 3 - 9 } & した自治体 & 1 & 2 & 3 & 4 & 自治体数 & 学校数 \\
\hline 単独校 & 1 & 44 & & & 2 & 46 & 52 \\
\hline 単独校+組合立校 & 2 & & $1,(1)$ & $2,(1)$ & & 4 & $3,(2)$ \\
\hline \multirow{5}{*}{ 組合立校 } & 2 & $14,(14)$ & & & & 27 & $(14)$ \\
\cline { 2 - 9 } & 3 & $13,(13)$ & & & & 39 & $(13)$ \\
\cline { 2 - 8 } & 4 & $11,(11)$ & & & & 44 & $(11)$ \\
\cline { 2 - 8 } & 5 & $2,(2)$ & & & & 10 & $(2)$ \\
\cline { 2 - 8 } & 小計 & $84,(40)$ & $1,(1)$ & $2,(1)$ & 2 & 計170 & 計97,(42) \\
\cline { 2 - 7 }
\end{tabular}

注）（）内の数值は組合立中学校の数を示す。

229 市町村で、当時から鳥取県の市町村は小さな人口規模であった。 1947 年には図 4 に示寸通り 2 市 22 町 146 村の計 170 市町村と なり、およそ 50 年間に市町村数は 68 減少しているものの、鳥取・ 智頭・三朝・米子以外の市町村の区域はほとんど変化がなく、合併は 進んでいない。また、図 5 に示寸通り 1947 年時点の自治体面積は 平均 $20.9 \mathrm{~km}$ 、人口は平均 3,470 人と小規模な自治体が多い。このよ

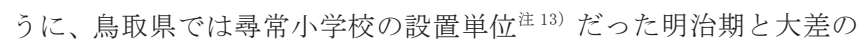
ない小規模自治体を基本に中学校を設立する必要があり、複数の小 規模自治体による組合立中学校設立の推奨を始めとして、様々な困 難に直面することになる。

\section{2 中学校の創設 (1947 年から 1949 年)}

新制中学校制度の実施のために鳥取県では「新学制実施準備協議 会」が組織され、県内に設置される中学校の基本的な方向が検討され た。その内容として、組合立を原則とした 12 学級 600 人を基準と した方針を定め、当初は 87 校の大規模学校構想の試案を示してい た ${ }^{11,12)} \cdot$ 注 14 )。但し、中学校の設置·管理は各市町村の管轄であり、 国の指針と市町村の実状を踏まえ県内に 97 校の中学校が設立され た注 ${ }^{15)}$ 。創設期の自治体別学校数を表 1 に示す。9 97 校中単独校は 55 校 $(56.7 \%)$ 、組合立校は 42 校(43.3\%)である。組合立を勧奨されて いたが、現実には校区・校舎の問題、住民の地域間の対立もあり、実 情は小規模の単村立の独立校が 44 校も開設された ${ }^{13)}$ 。1 自治体に 4 校設立しているのは鳥取市と米子市のみで注 ${ }^{16)}$ 、他の単独校は 1 自 治体に 1 校設立する形である。また、単独校+組合立の複数校を設 立している自治体は智頭町と倉吉町の 2 町である。組合立は 2 自治 体で組合立を設立した中学校が 14 校、3 自治体が 13 校、 4 自治体 が 11 校、 5 自治体が 2 校で、鳥取県の多くの自治体は単独で中学校 を設立することが困難であったものと推測される。

次に新制中学校設立時の中学校分布を図 6 に示す。組合立中学校 を設立した自治体は比較的面積が狭い特徴を有す。中には面積が広
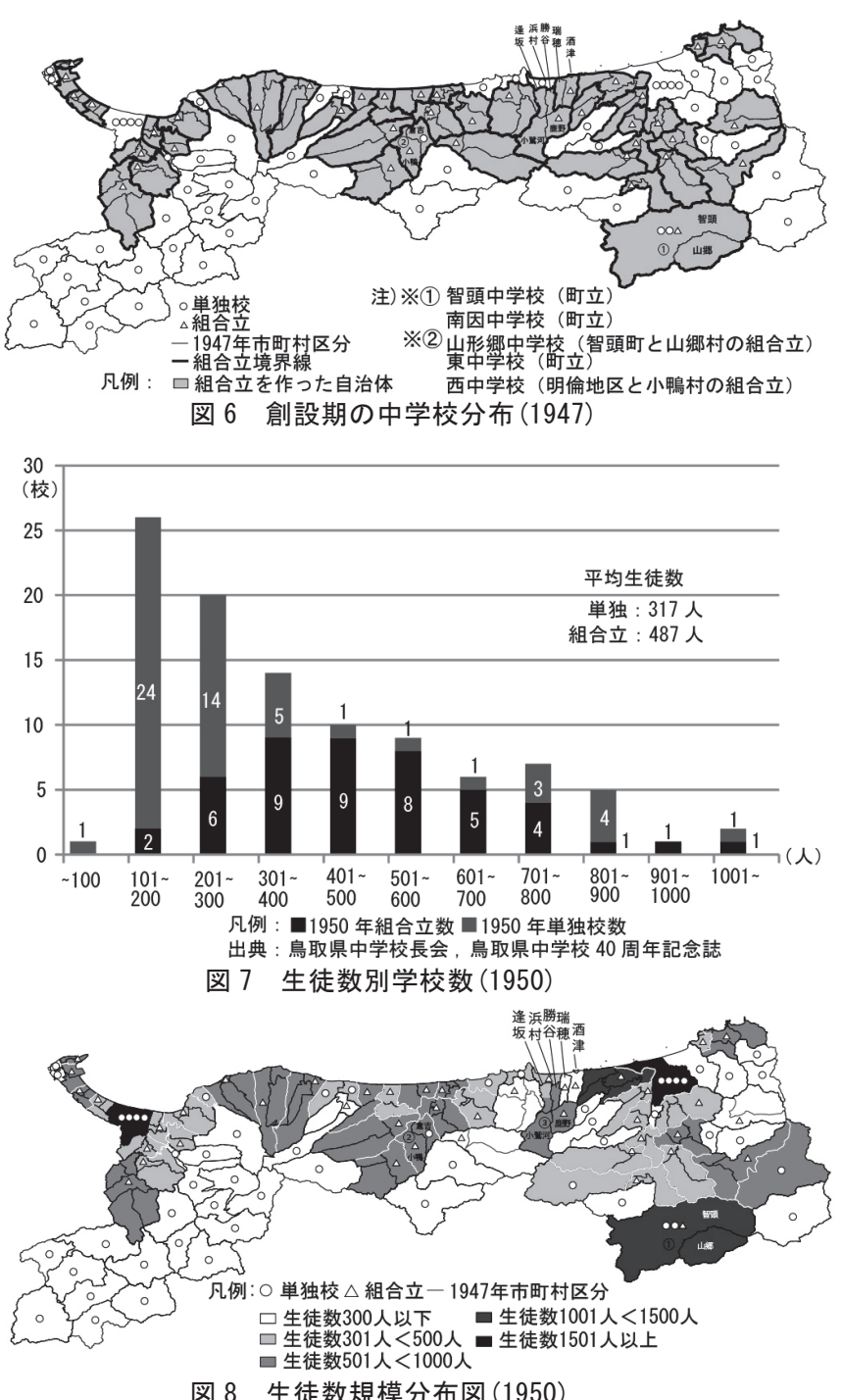

い自治体もあるが、町立と組合立の複数校を設立している。大山以 西の中国山間部沿いの日野郡 17 校がいずれも単独校として設立さ れている点が特徴で、この地域は特に冬季の通学に困難を伴うため、 町村単位で単独校を設立したものと考えられる。現在の江府町や日 南町では冬季寄宿舎を設置した上で統合が行われた ${ }^{17}$ )。図 5 の自 治体面積・人口と比較すると、単独校のみを設置した町村の特徴は 2 タイプに分けられる。第一(図 5 中の(1) は日本海側の面積 $20 \mathrm{~km}$ 以下 かつ人口 4 千人 5 千人規模の町村で、鳥取県内では人口集積が平 均以上の町村である。第二(同(2))は人口規模によらず面積が $20 \mathrm{~km}$ 以 上の町村で、特に $50 \mathrm{~km}$ 以上の山間部 13 町村が単独校のみを設置し ている(同(3)。

\section{3 創設期の学校数と生徒数}

創設期の中学校の生徒数別学校数を図 7、各自治体の生徒数規模 を図 8 に示す。全体的には 101-200 人規模の中学校が最も多く、次 いで 201-300 人の順である。鳥取県の方針である 600 人を満足す る中学校は 1950 年時点で 101 校中 21 校(20.8\%)に止まり、当初 の方針通りには進んでいないことから、戦後間もない新制中学校創 設期には小規模校が多いという課題を抱えていた。また、単独校は 生徒数規模 101-200 人の中学校が 24 校、201-300 人規模が 14 校 と、単独で開校されたものの生徒数は小規模な学校が多く、平均生 
表 2 開校時の校舎の状況（1947 年）

\begin{tabular}{|c|c|c|c|c|c|}
\hline & 転用校舎数 & 併置（間借り)校舎数 & 転用+間借り & 新筑 & 小計 \\
\hline 小学校 & 4 & 38 & & & 42 \\
\hline 青年学校 & 8 & 0 & & & 8 \\
\hline 高等科 & 2 & 2 & & & 4 \\
\hline 公用建物 & 1 & 0 & & & $\frac{1}{1}$ \\
\hline 李修学校 & 1 & 1 & & & 2 \\
\hline 独立校全 & & & & 1 & 1 \\
\hline 小学校＋背年学校 & 0 & 12 & 3 & & $\frac{15}{15}$ \\
\hline 複数の施設 & 1 & 14 & & & 15 \\
\hline 不明 & & & & & $\overline{9}$ \\
\hline 小計 & 17 & 67 & 3 & 1 & 97 \\
\hline
\end{tabular}

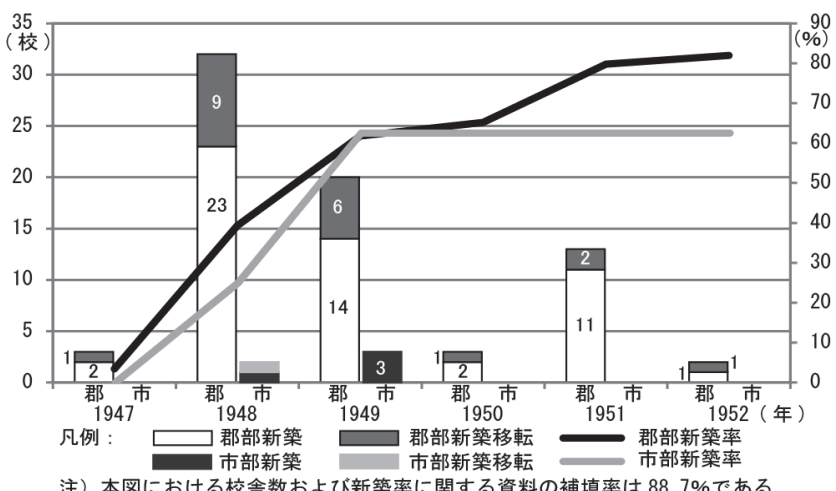

注）本図における校舎数および新築率に関する資料の補填率は $88.7 \%$ あるる

図 9 郡部と市部の年代別校舎新築数

徒数は 317 人である。市町部では 600 人以上の生徒数規模の中学 校もあるが、郡部では殆どが 300 人以下である。単独で中学校を設 立した自治体は、面積が広く通学距離の問題があるため組合立の創 設が困難な状況にあったものと推測される。これに対し組合立中学 校は、生徒数規模が 101-200 人の中学校が 2 校、201-300 人の中 学校も 6 校のみで、301-600 人規模の中学校が多く、単独校とは対 照的な状況を示し、平均生徒数は 487 人である。一部生徒数規模 300 人以下の中学校があるものの、生徒数規模は 300 人から 1,000 人 の中学校が多い。鳥取県では小規模自治体が多く、生徒数確保の点 で自治体単位での中学校創設が困難で、県の方針である 12 学級 600 人を満たすよう組合立による中学校を創設し学校の適正規模 確保を目指していたものと考えられる。

\section{4 創設当初の校舎の確保と新築に向けた自治体の対応}

1946 年の教育刷新委員会の中で新制中学校は「独立校舎とするこ と」という方針が示されていたが、当時の地方財政は逼迫し物資も不 足し、開校までの準備期間も短かったことから、新たに独立校舎を 確保することは困難な状況であった主 ${ }^{18)}$ 。1947 年の鳥取県内の校舎 の状況を表 2 に示す。当時の全 97 校の中で独立校舎新築は 1 校の みで、戦前より使用されていた小学校を間借りもしくは転用した中 学校が 42 校と 4 割以上を占める。その他にも小学校と旧青年学校 の両方を間借りし分散開校したものや他の複数の施設(兵舎・工場・ 教員住宅等)の間借りも多く、各自治体で施設確保のために様々な工 夫が試みられた注 19,20)。

開校当時、間借りや転用によって校舎を確保していた状沉から、 その後は専用校舎の建築が各自治体で進められた。新築校舎数を郡 部と市部(鳥取・米子市)に区別し、1947 年から 1952 年まで示したの が図 9 である。1947 年の新築・新築移転は郡部で 3 校が見られる。 1948 年からは多くの新築が行われるようになり、郡部・市部共に 1949 年には約 $60 \%$ を超える中学校が新築を行っている。尚、当初 の建替え段階では RC 造校舎はなく、木造校舎が中心であった注21)。
表 3 鳥取県知事による市町村合併勧告例の抜粋

市町村規模の適正化につきましては、(中略)政府としても重要施策の中にとりあげられ(中 略) 逐次推進されている(中略)。ところが何分にも歴史的、地理的伝統を有する市町村に大 変革を加えるという大事業でありまして、(中略)必ずしも所期の成果をあげ得ていないのが 現状であります。県下市町村行政を御見受けしまして痛感致しますことは、(中略財政面か らの制約により、緊急なしかも重要な施策を放棄の止むなきに至っている向の相当多い之 いうことであります。・市町村本来の目的たる助長行政や災害復旧行政その他公共事業等 には殆んど手も足も出ない現状であり、(中略)。何と申しましても地方財政の確立と健全化 ということは、緊急の要務であります。これらの解決策につきましては、(中略)市町村自らの 創意でこの問題を打開しなければならないのでありまして、ここに市町村の規模の合理化と いうことが大きく浮かび上がって来るのであります。特に市に関しましては、最近政府におき ましても終戦以来その権限の地方移譲に伴う弱小都市の濫立を防止し、真に都市としての 実力あり且つ名実伴うもののみに限定し、その育成強化につとめる方針に基づき、その設 立等に関する地方自治法の規定の一部改正が今国会で審議されつつあります。(中略)この 際目前の小異を捨て将来への飛躍的発展を期し、その基本的基盤たる市域拡充強化のた め、隣接町村の合併に特別の御考慮御研究を煩わしたいのでありまして、(後略)

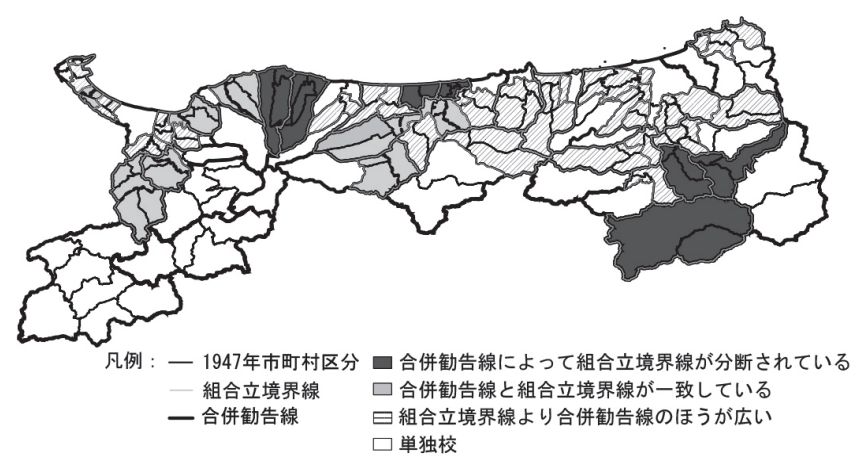

図 10 合併勧告区域と組合区域の関係

表 4 合併勧告前後の市町村数

\begin{tabular}{|c|r|r|r|l|}
\hline & $\begin{array}{c}\text { 市町村数 } \\
(1950)\end{array}$ & $\begin{array}{c}\text { 合併歓告での } \\
\text { 町村数 } \\
(1952)\end{array}$ & $\begin{array}{c}\text { 合併後の } \\
\text { 町村数 } \\
(1960)\end{array}$ & 注釈 \\
\hline 鳥取市 & 1 & 1 & 1 & \\
\hline 米子市 & 1 & 1 & 1 & \\
\hline 岩美郡 & 17 & 2 & 4 & \\
\hline 八頭郡 & 25 & 8 & 8 & \\
\hline 気高郡 & 26 & 2 & 3 & \\
\hline 東伯郡 & 43 & 11 & 9 & ※ 東伯郡より1953年倉吉市 成立 \\
\hline 西伯郡 & 40 & 8 & 9 & ※ 西伯郡より1955年境港市 成立 \\
\hline 日野郡 & 17 & 3 & 4 & \\
\hline 計 & 170 & 36 & 39 & \\
\hline
\end{tabular}

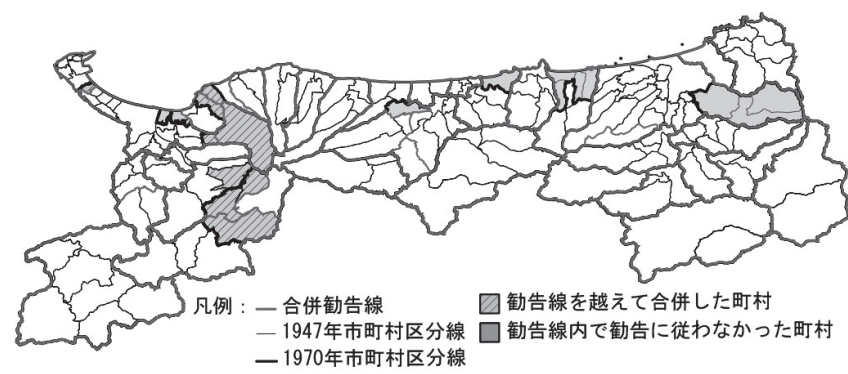

図 11 合併勧告区域と 1970 年の市町村区分

\section{4. 昭和の町村合併}

新制中学校の創設以後、僅か 6 年後には昭和の町村合併により大 規模な自治体再編が始まり、これに伴い中学校の統合が進められた。 そこで本章では先ず町村合併の経緯について分析を行う。

\section{1 町村合併钦告}

鳥取県では町村合併促進法施行前年(1952 年 7 月)に、各市町村長 に対し県知事名により市町村合併の勧告を行っている。市長・市議会 議長宛勧告の一部を抜粋注 ${ }^{22}$ したのが表 3 で、地方財政の確立と健 全化を実現するため、重要施策として自治体規模が小さな鳥取県の 市町村規模の適正化が挙げられた。

さらに勧告では具体的な市町村合併案「各郡市別町村合併锥告に 
基づく規模一覧表」が示され、「これは各郡に昨年(1951 年)十二月設 置致しました町村合併促進審議会に夫々諮り、研究審議の上、答申 を参酌し行ったものでありまして、自然的、社会的、経済的な諸条 件を勘案した結果最も適当と認めた案であります。」との解説が記さ れている。一覧表には具体的な合併対象町村名·現人口・合併後の計 画人口・合併計画図が記載されている。合併勧告線とかつて自治体で 作られた組合立の境界線の関係を図 10、合併勧告の計画市町村数と 合併後の市町村数を表 4 に示す。

合併衔告と組合立の自治体範囲が一致している例は殆どなく、組 合立設立自治体より勧告の方が広い自治体が多い。また組合立自治 体間を分断して新たな自治体を設立している例も多く、市町村合併 後の中学校の維持・管理の課題が各自治体で生じていたといえる。ま た表 4 より、1950 年の 170 市町村に対し合併锥告の計画市町村数 は 36 であった。この勧告を受けた合併後の市町村数は東伯郡から 成立した倉吉市と西伯郡から成立した境港市を加えた 41 市町村で、 概ね計画通りに町村合併が進んでいる。

次に町村合併後の自治体と合併勧告の関係を図 11 に示寸。大半 の自治体が組合立構成自治体とは無関係に合併勧告通り市町村合併 を行っている。一部勧告に従わず合併を行った自治体もあるが、大 部分の自治体では表 4 の計画通りに合併が行われている。

\section{2 町村合併の経緯}

鳥取県の合併による市町村数推移を図 12 に示す。結果として、 1950 年時点の市町村数 170 ( 2 市を含む)が 1953 年 11 月には 121 に減少し、1956 年 9 月には 53(4 市を含む)市町村にまで合併され た。その後は 1960 年時点で 41 市町村(4 市を含む) となっている。 このように、町村合併促進法の施行期間(1953.10.1-1956.9.31)の 1953 1955 年の間に合併のピークがあり(この期間内に 7 割減少)、 1956 年の新市町村建設促進法の制定以前に合併が重点的に促進さ れている。特に鳥取・米子市では周辺の小規模町村の大規模な吸収合 併により市の面積が 2 倍以上に拡大している注 23$)$ 。郡部においても 山口県と比較すると「県の勧告」の影響とも考えられる $3 \sim 7$ 村の大 規模合併が目立ち注 24)、特に岩美町は 1954 年 7 月に 9 町村による 合併で設立された。

当時の状況として鳥取県教育史の抜粋注 25) を表 5 に示す。鳥取県 では、1952 年 11 月の 165 市町村が 1956 年 7 月には 53 市町村と 町村合併が推し進められたが、県教育委員会でもこの機会に小規模 校の統合を推進しようとした意図もうかがえる。

\section{3 町村合併の結果}

町村合併前後 $(1950,1970$ 年)の各自治体の面積と人口を図 13 に示 す。面積は、合併前は $10 \mathrm{~km}$ 以下の市町村が $71 / 170$ 自治体(42\%) あり、40 kn'²下の自治体が多く存在していた。合併後は $10 \mathrm{~km}$ 以下 は日吉津村のみで注 ${ }^{26)}$ 、 $81 \mathrm{~km}^{2}$ 以上の自治体が増加している。人口は、 3 千人以下の自治体が $117 / 170$ 自治体と $69 \%$ を占め、全体では 5 千 人以下の自治体が 9 割近くに及んでいた。合併後は 5 千人以下の自 治体が激減し、合併前には殆ど見られなかった 6 千人以上の自治体 が増加した。特に 1 万人を超える自治体が 4 市町から 10 市町に増 加し注 27)、中には人口密度の低い山間部で大規模な合併例もあり、 日南町 $341 \mathrm{~km}^{2}$ (人口 1.1 万人, 32 人/ kmin)、智頭町 $225 \mathrm{~km}^{2}$ (人口 1.2 万 人,55人/ kmin)等となった。以上より、町村合併促進法の適正規模(人 口 8 千人)の通達が大きな影響を及ぼしたことが分かる。

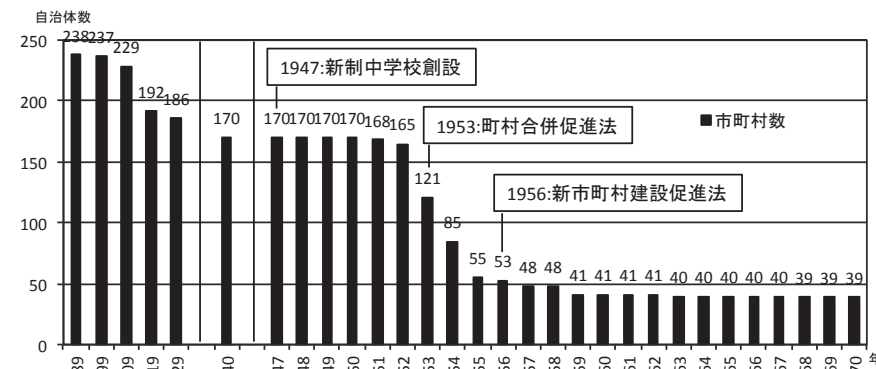

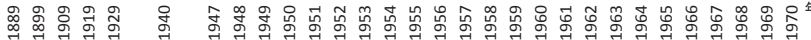
図 12 市町村数の推移

表 5 町村合併と学校統合経緯 (鳥取県教育史より抜粋)

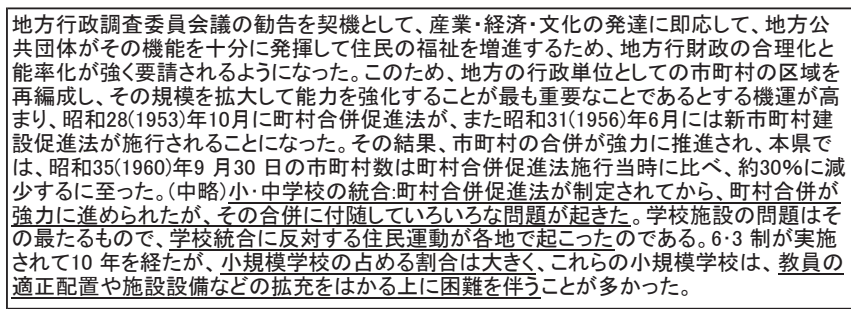
適正配置や施設設備などの拡充をはかる上に困難を伴うことが多かった。

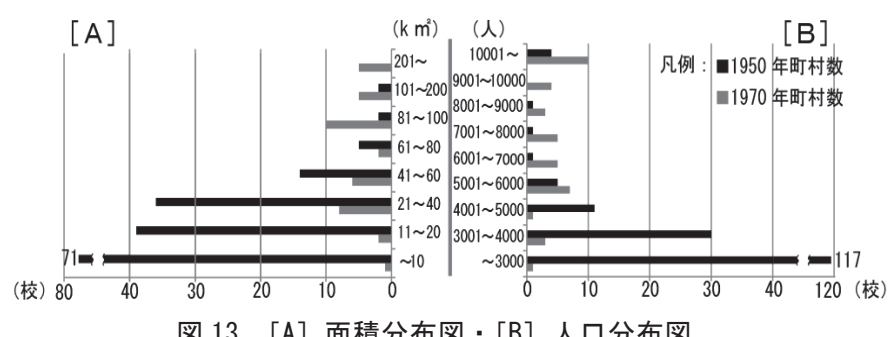

\section{5. 中学校の統合過程}

5.1 中学校統合の背景 (1949 年から 1953 年)

鳥取県における学校統合は、特に統合の対象が中学校に向けられ、 戦後新制中学校発足以来の小規模学校の教育効果があがらないこと の懸念、財政的な非効率から、1949 年から重要施策として検討され、 県教育委員会において翌 1950 年には、「中学校整備強化の原則的事 項」として、具体的な統合の形態と統合実施に関する原則的事項が定 められた ${ }^{14)}$ 。「統合の形態」としては、「(1)教育職員免許法の施行に 伴う中学校の教科運営を可能にするような生徒数 600 人を標準之 する組合立中学校に統合する。(2)数ヶ町村の、一部事務組合の中に 行政区画にとらわれないで、新しく学区を編成して組合立中学校を つる。(3)地理的条件によって適当な規模の中学校にすることが可 能な範囲で学校ブロックをつくる。」とされ、多くの組合立中学校の 設置と、その後の中学校統合に影響を及ぼしたと考えられる。

また、上記「中学校整備強化の原則的事項」の「実施についての原則 的事項」としては、「(1)通学距離は片道 $8 \mathrm{~km}$ 以内にする。(2)季節的 に通学困難なものには寄宿舎を設置する。(3)暫定的建築であって本 建築に着手していないもの。(4)小学校と併設し、同一施設又は同一 校庭を使用し、相互に教育効果をあげる上に支障となっているもの。 (5)財政的に極めて困難な状態にある中学校(ただし、通学距離 $8 \mathrm{~km}$ 内外であっても、四季を通じて通学困難のもの、本建築が完了して 特別教室など施設の充実しているものは、例外として十分考慮す る)。」とされ、創設期に青年学校の転用や小学校の間借りで賄われ ていた中学校校舎の整備とも合わせて統合が考えられた。

さらに、県教育委員会事務局内に「中学校整備強化促進委員会」が 
表 6 昭和の合併協定書に記載された学校の維持・統合の方針、並びに 1970 年代前半までの動向

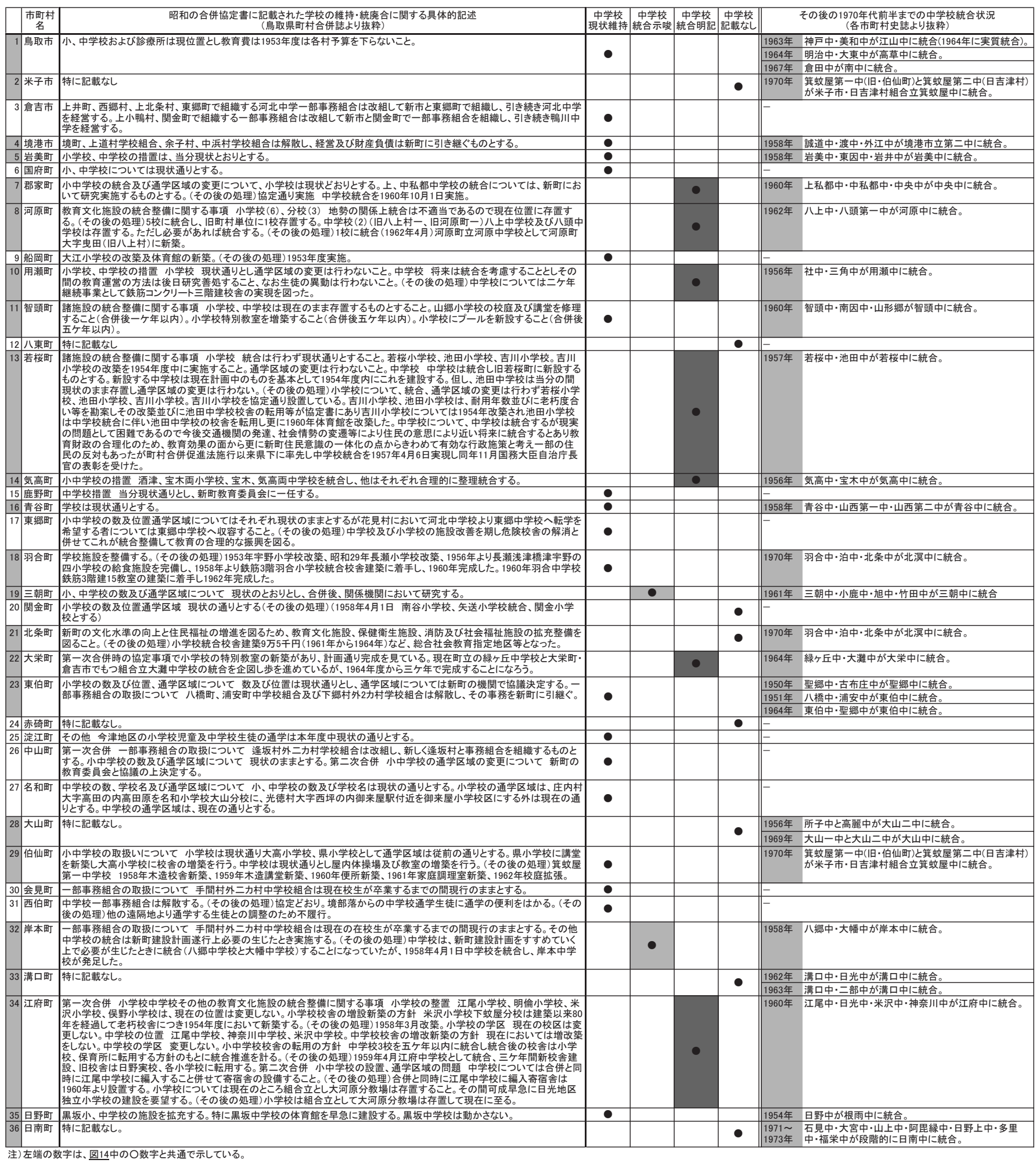

設けられ、統合対象 11 力所(該当 22 校)を決定し、統合勧奨を進め 実現に努めた。この結果、1952〜1953 年にかけて、統合校 5 校(聖 郷・東伯・淀江・鴨川・根雨中) 一の再編が実施され、特に聖郷中では山 間部遠隔地区生徒のために県内初のスクールバスの運用と共に統合 後に寄宿舎も新築している注 ${ }^{28)}$ 。「(統合)実施についての原則的事項」 内に「(2)季節的に通学困難なものには寄宿舎を設置する」とあるよ うに、冬季に積雪量の多い山陰地方では統合時に遠隔地区の生徒へ
の通学・宿舎支援の必要性もあった。このように全国に先駆けて着 手された鳥取県の学校統合注 29$)$ は、1954 年以降「学校統合五か年計 画」が逐次発表され、市町村合併の促進と相まって強力に推進され、 図 2 に示寸通り中学校の統合は 1974 年まで見られる。

\section{2 町村合併に伴う自治体の中学校の維持・統合の方針}

1950 年代の町村合併時の合併協定書に記載された各自治体の学 校の維持·統合方針に関する部分 ${ }^{15)}$ を抜粋整理したのが表 6 である。 


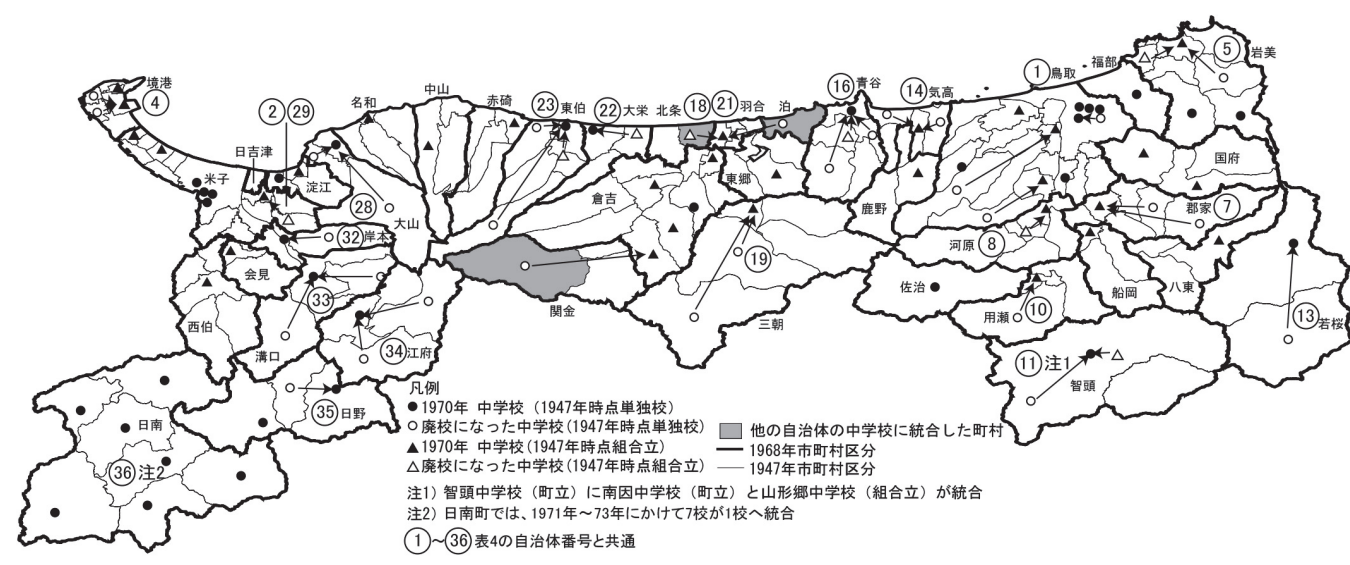

図 14 中学校分布 (1970まで)

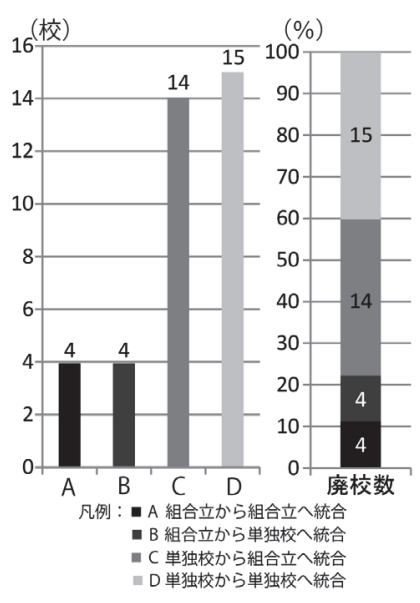

図 15 廃校の統合パターン

表中央列に整理したように、町村合併に伴い成立した 36 自治体の 内、合併協定書に中学校を現状維持としたのが 19 自治体、将来の 統合を示唆したのが 2 自治体、統合を明記したのが 7 自治体、小学 校を含め学校に関する記載がないのが 8 自治体である。また、表右 に町村合併後から 1970 年代前半までの中学校統合状況を各市町村 史誌よりまとめた。これらを照合すると、将来の統合を示唆した 2 自治体と統合を明記した 7 自治体の計 9 自治体の全てで 1956 1964 年の間に中学校を統合し、1 町 1 中学校としている。これら 9 自治体は町村合併が中学校統合と密接に関係した事例といえる。さ らに、1970 年代前半までの中学校統合状況より、合併時の合併協定 書では現状維持または特に記載なしの 27 自治体の内、 13 自治体が 1954 年以降に中学校を統合し、多くが 1 町 1 中学校としている。 この結果、昭和の町村合併により成立した 36 自治体の内、6 割以上 の 24 自治体で第二次ベビーブームが起こる 1970 年代前半までに中 学校の統合を進め、多くの町村では 1 町 1 中学校となり、町村合併 とその区域設定が中学校統合の時期や範囲に大きな影響を及ぼした。

\section{3 中学校統合の経緯 (1953 年から 1970 年)}

1970 年までの中学校分布を図 $14^{\text {注 } 30)}$ 示す。1947 年時点で組合 立中学校を設立していた自治体も合併後の自治体区分に合わせ統合 を行っている。ただし、一部の自治体の統合中学校 2 校では将来の 生徒数減少に伴う学校運営への危機感から、自治体区分を越え隣接 する自治体と統合を行っている注 31 。廃校 37 校を見ると、1947 年 時点の単独校 29 校、組合立 8 校が 1970 年までに廃校になっており、 県内全域において創設期の単独校の多くが統合されている。また、 統合を行った 24 自治体中、日本海に面さない 12 自治体では、いず れも中国山地側から日本海側へ、もしくは海側に向かう主要街道沿 いの方角へ向けて統合されている。残りの日本海に面する 12 自治 体においても、内 5 自治体 (大山・東伯・青谷・鳥取・岩美)ではより一 層日本海側の方角へ向けて統合されている。全体として、合併後の 自治体内のより日本海側の開けた地域に立地する中学校一統合され たことが読み取れる。尚、単独校が多く設立されていた鳥取県西部 でも多くの中学校が 1970 年までに統合を行ったが、図 14 注 2 に示 す日南町では 1970 年代前半に 7 校が 1 校に統合された注 32 。

廃校 37 校の統合パターンを図 15 に示す。単独校から単独校へ統 合を行ったパターン D の 15 例(40.5\%)は、大山以西の単独校創設 が多かった鳥取県西部に多い。特に大山周辺の中山間地域の 5 町(

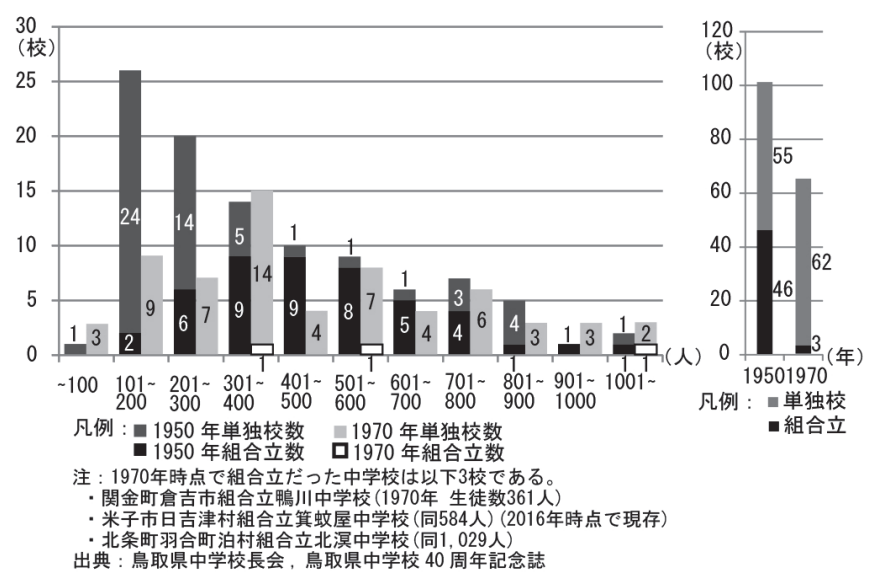

図 16 生徒数別学校数 (1950-1970)

大山・岸本・溝口・江府・日野)では、合併後の自治体内の生徒数の少な い単独校同士を統合している。次に単独校から組合立へ統合したパ ターン C の 14 例(37.8\%) は生徒数の少ない単独校を合併後の自治 体内の比較的生徒数の多い旧組合立中学校に統合したものである。 特に中部の三朝、東部の郡家や用瀬等の関金以東の中部東部の中山 間地域で見られる。組合立で創設されたにもかかわらず他校へ統合 され廃校となったパターンA とパターン B が 8 例(21.6\%)ある。その 一方で、創設期に組合立として設置された 42 校の内、パターン C と パターンAの組合立 18 校が統合先として存続したことは、組合立 として創設し一定の生徒数規模を確保した方策が、学校の存続に有 効であったことを示している。

次に町村合併前の 1950 年と合併後の中学校再編が概祆完了した 1970 年時点の生徒数別学校数を図 16 に示す。1950 年時点では、 小規模校の多い単独校に対し、概补適正規模に近い生徒数の組合立 という関係にあったが、1950 1970 年の 20 年間で 40 校弱が減少 し、1953 年以降の町村合併に伴い旧自治体間の組合立から新町村立 単独校への移行が進められ、1970 年時点で組合立は 3 校のみとな った。この結果、1970 年時点の中学校は生徒数 301 人以上が全体 の 7 割(46 校)を占め、多くの中学校が旧組合立に近い規模へ統合さ れ、1950 年時点の生徒数 300 人以下の学校が大幅に減少したが、 町村合併と学校統合後も生徒数 200 人以下の小規模校が 12 校あり、 その後の更なる小規模化をもたらすことになる。 


\section{6. 結論}

明治期には戸長区と小学区の再編調整を経て町村合併が実施され 16)、その後に小学校の義務教育化が実現しており、学校を設置する 地方自治体の改革が優先された。しかし、戦後の日本では新制中学 校の設置が先行し、自治体再編が後行したため、様々な混乱をもた らした。本論では鳥取県を対象に、昭和の町村合併と新制中学校統 合の関係についてその歴史的経緯を実証的に整理した。

1) 新制中学校設立の際、鳥取県では当初 87 校の大規模学校構想 が計画され、原則組合立で 12 学級 600 人規模の中学校を設立す る方針であったが、校区・校舎の位置、冬季や距離上の通学問題、 住民感情等から、97 校(組合立 42 校、単独校 55 校)が設置された。 1950 年時点には、 600 人を満たす中学校は市町部を中心とする $20.8 \%$ に止まり、郡部を中心に 8 割の小規模校が存在するという 課題を抱えていた。特に組合立は方針の規模に近い生徒数であっ たのに対し、単独校は小規模校が多かった。

2) 昭和の町村合併期には 1950 年の 170 市町村が 1960 年には 41 市町村となった。そしてこの機会に県教育委員会でも中学校統 合の具体的な勧奨を実施する等、小規模校の統合が推進された。 鳥取県の中学校再編は 1949 年から重要施策として検討され、全 国に先駆けて行われた。1950 年には具体的な「統合の形態」と「統 合実施についての原則的事項」が定められ、さらに 1954 年以降も 「学校統合五か年計画」が逐次発表され、昭和の町村合併の促進と 相まって強力に統合が推進された。

3 ）昭和の町村合併時の合併協定書を取り決めた 36 自治体の内、 21 自治体において 1970 年代前半までに中学校の統合が進められ、 多くの町村部で 1 町 1 中学校となった。昭和の町村合併とその区 域設定が中学校統合の時期や範囲に大きな影響を及ぼしたことが 確認された。

4 ）鳥取県は明治の町村合併後の自治体数が多く、1947 年時点まで こうした小規模自治体の多くが存続したことが、中学校創設時の 学区や学校数を規定する条件となった。1948 から 1949 年には厳 しい財政事情の下で校舎の新設が行われ、組合立中学校創設に向 けた取組みもなされた。こうした中で、1953 年以降の急速な町村 合併により、それまでの経緯とは関係なく中学校の再編統合が進 められたことは、義務教育施設の設置に対し自治体改革が遅れた 場合にもたらされる課題を歴史的事実として示している。

5 ) 1954 年以降は県主導の強力な町村合併の推進に歩調を合わせ、 県教育委員会の学校統合計画に基づいて中学校の統合が行われた 結果、鳥取県では中国地方の他県と異なり II 期までに中学校の再 編をほぼ完了した。鳥取県における早期の統合計画の実施は、 1970 年代以降に少子化が進む中で 40 年にわたる安定的な中学校 の継続運営に寄与したとも言える。

6 ) 新制中学校創設期に組合立で設立された 42 校の内、1970 年時 点で 18 校(5.3の A・C パターン)が他校との統合時に統合先とし て存続したことは、組合立として創設し一定の生徒数規模を確保 する方策が、自治体再編に合わせた統廃合の動きの中でも、学校 の存続に対し有効な設立方法であったと言える。

鳥取・島根の山陰両県では現在も少子化により小中学校の児童生 徒数の減少が進んでおり ${ }^{17}$ 、昭和の町村合併時の自治体範囲内に小 中学校を残寸手段の一つとして、施設一体型校舎注 ${ }^{33)}$ の小中一貫校
の設置が進められている注 ${ }^{34)}$ 。半世紀にわたる中学校とその地域的 つながりを残したいという地域住民の希望は強いと推測されるが、 こうした近年の小中学校の再編動向の把握と地域施設計画論として の位置付け及び評価に関しては今後の課題としたい。

尚、本研究は日本学術振興会科学研究費 $(25289210)$ 及び鳥取県 環境学術研究等振興事業の助成を受けたものである。

注

注 1) 町村合併促進法 : 第一条 この法律は、町村が町村合併によりその組織 及び運営を合理的且つ能率的にし、住民の福祉を増進するように規模の適 正化を図ることを積極的に促進し、もつて町村における地方自治の本旨の 充分な実現に資寸ることを目的とする。第三条 町村は、おお拈む视八千人以 上の住民を有するのを標準とし、地勢、人口密度、経済事情その他の事情 に照らし、行政能率を最も高くし、住民の福祉を増進するようにその規模 をできる限り増大し、これによつてその適正化を図るように相互に協力し なければならない。

注 2)「町村合併促進法」施行以降、市町村数は全国で 10, 505 (1947 年) から 3,975 (1956 年)になった。鳥取県では 1947 年当時の市町村区域の大半は明 治 22 年 (1889 年)の市制・町村制施行当時のままで、170 市町村あったが、 1956 年には 53 に、さらに「新市町村建設促進法」によって 1963 年には 40 になった。この町村合併促進により、1953 年から 1970 年代前半期に中学 校の統合が行われた。

注 3）新市町村建設促進法 : 第一条この法律は、町村合併を行つた市町村の 新市町村建設計画の実施を促進して、新市町村の健全な発展を図り、あわ せて未合併町村の町村合併を強力に推進することにより、地方自治の本旨 の充分な実現に資することを目的とする。

注 4）「公立小・中学校の統合方策についての方針(中央教育審議会)」において 小規模校の統合規模として「概敉 12 学級ないし 18 学級を標準とする」、 通学距離は「小学校児童は $4 \mathrm{~km}$ 、中学校生徒は $6 \mathrm{~km} 」 の$ 基準が示された。

注 5）義務教育諸学校施設費国庫負担法とは、公立の義務教育諸学校等の施 設の整備を促進するため、学校建物の建築に要する経費について国がその 一部を負担することを定めるとともに、文部科学大臣 (文部大臣)による施 設整備基本方針の策定及び地方公共団体による施設整備計画に基づく事業 に充てるための交付金の交付等について定め、もつて義務教育諸学校等に おける教育の円滑な実施を確保することを目的としたものである。

注 6) 参考文献 9 の p. 33 より、1950 年の鳥取県の町村平均人口は 2,856 人、 全国の同人口は 5,115 人であり、鳥取県内の町村は小規模だった。

注 7) 組合立学校とは、地方自治法に基づき複数の自治体が一部事務組合を 設けて運営する公立学校を指す。1947 年 1 月の教育刷新委員会議決の学制 改革実施計画案において「中学校 2. 市町村はその區域内にある義務就學 者を収容するに必要な中学校を設置すること。學校組合を認めることは従 来通りとすること。」とあり、戦前も学校組合の制度は一般的に用いられ ていたことが分かる。

注 8) 図 1 の学校推移数、学校数増減率には中学校分校は含まれておらず、 中学校本校のみの数字である。

注 9）ベビーブーム等による生徒数の増減状況から、1949-1962 年までを I 期、1963-1977 年までを II 期、1978-1987 年までをIIII期、1988-2002 年ま でをIV期、2003-2011 年までをV 期に区分している。

注 10）島根県教育委員会では 1950 年に「組合立中学校設置勧奨の基本方針」 を定め、当時の学校数 250 校の内で、組合立勧奨の対象学校数 170 校・成 立後の組合立学校数 70 校・減少する学校数 100 校を目標に統合が進められ た（島根県中学校教育 20 年史, pp. 12-14, 1968 参照）。

注 11）鳥取県では第二次ベビーブーム世代の中学校入学や宅地開発と共に、 1985 年から 1995 年にかけて、鳥取市・境港市・米子市・北条町の 4 自治 体において中学校の分離新設が行われた。

注 12) 図 3 は http://tamotchi. skr. jp/geo/hensen31/index. html や鳥取県史 などの情報を基に筆者が作図したものである。

注 13) 1886 年 (明治 19)に「小学校令」により、尋常小学校 4 年間が義務教 育となり、1887 年には鳥取県内各集落に尋常小学校や簡易小学校が開設さ れた。1 889 年「市制・町村制」により、明治の町村合併が行われ 238 市町 村となって地方自治制度が確立すると共に、1890 年に新たな「小学校令」 が公布され、市町村もしくは町村学校組合の負担で尋常小学校を設置する ことが定められた。(鳥取県教育史, pp.447-455, 1957、日南町史, 自然・文 化, pp. 153-167, 1984 参照)。 
注 14）鳥取県では新制中学校の発足前の 1947 年 2 月〜 3 月に新学制実施準備 協議会での協議の結果、新制中学校学区設定試案が発表された。ここでは 組合立を原則とした 12 学級 600 人を単位基準とする 87 校の大規模中学校 構想が示された。設置については、中学校の将来のために、1. 地域社会の 教育環境の拡大、2. 独立校舎の確保、3. 教育内容・教育組織の充実、4. 教 育経費（財政）の健全化等の観点から、組合立中学校の設立を理想とされ たが、最終的な学校設置案は試案よりも多い 96 校が設置され、小規模校も 多くあった（鳥取県教育史, 戦後編, pp. 39-48, 1959 参照）。

注 15）鳥取県史, 近代, 第 4 巻, pp. 161-163, 1969, 創設期の新制中学より、1947 年創設の新制中学校は 96 校が設立されたが、本論文では 1948 年に設立さ れた鳥取市立鳥取南中学校を加えた 97 校としている。

注 16）鳥取県教育史, 戦後編, p. 53, 1959 に掲載された発足当時の中学校一覧 等によれば、1947 年 4 月に米子市では第一から第四までの 4 中学校、鳥取 市では鳥取北・西・東の 3 中学校が発足している。続いて 1948 年 4 月には 鳥取市で鳥取南中学校が発足していることから、創設期に鳥取市では 4 校 が単独開設されたとしている。

注 17）山間部の日野郡の中学校統合には、冬季用の寄宿舎を整備する必要が あった。現在の江府町では 1960 年の江府中学校への統合に際し、寄宿舎も 整備された (江府町史, p. 980, 1975 参照)。また、現在の日南町でも 1974 年 の日南中学校への統合に際し、寄宿舎も整備された (日南町史, 自然・文化, 昭和, p. 323, 1984 参照)。

注 18) 1946 年 10 月 25 日,教育刷新委員会第八回総会 特別委員会 中間報告 注 19）創設期の中学校校舎の設置状況については「開校はしたものの、独自 の校舎もなく、その学習指導は小学校の間借り、青年学校、その他倉庫等 を利用したり、講堂の間切教室、甚しくは青空教室といって野外で行われ た。しかも二部授業、三部授業の変則授業すら生じたのである」(鳥取県教 育史, p. 29, 1979 参照)。

注 20） 1947 年の新制中学校創設では、各市町村が戦後の混乱期に校舎・教員・ 財源面で苦慮したことが各市町村史に記載されている。日南町でも、「各 村では新学制実施準備協議会を作って、新しい中学校を間に合わせること に苦心した。小学校は国民学校がそのまま使用されたが、中学校には校舎 もなく教員もいなかった。やむなく、校舎は青年学校を使ったり、小学校 の建物や公会堂その他を借用した。国の補助金も乏しく村の財政も深刻で、 その解決のために、村長はじめ関係者の長期にわたる必死の努力が重ねら れた」（日南町史, 自然・文化, p. 186, 1984 参照）。

注 21）鳥取県内での RC 造中学校校舎の建設は、市町村誌によれば、1955 年 3 月の大村・用瀬町・社村の町村合併時に統合中学校の建築が始められ、 1956 年 4 月社・三角の両中学校が統合され、1957 年 2 月新敷地に鉄筋コン クリート三階建ての用瀬中学校校舎 $\left(3,038 \mathrm{~m}^{2}\right)$ が完成したのが最初であ る。引き続き、1958 年 3 月八郷、大幡中学校の統合による岸本中学校の開 校を控えて、同年 1 月鉄筋コンクリート三階建てが完成している。また、 米子市中学校教育史では 1960 年頃より RC 造に移行したとの記載もある。

注 22）鳥取県町村合併誌, p212, 1964 より抜粋

注 23）鳥取県統計年鑑によれば、近隣町村との合併により鳥取市の面積は 1952 年の $43.8 \mathrm{~km}$ から 1954 年には $218.0 \mathrm{~km}$ に、米子市の面積は $30.8 \mathrm{~km}$ か ら 73.9 km拡大している。

注 24) 郡部の主な大規模合併例は、東部では岩美町 (9 町村合併)、郡家町 (6 町村)、河原町 (6 町村)、青谷町 (5 町村)、気高町 (5 村)。中部では三朝町 (5 村)。西部では日南町 (7 村) 、西伯町 ( 5 村) がある。

注 25）鳥取県教育史, p. 523, 1979 より抜粋

注 26）日吉津村の面積は $4.2 \mathrm{~km} 2$ である。製紙企業の企業城下町であり、米子 市に隣接する。2017 年現在でも鳥取県唯一の村として存続しており、中学 校は米子市との組合立箕蚊屋中学校を運営する。なお、箕蚊屋中学校は 2017 年現在では県内唯一の組合立中学校である。

注 27） 1950 年で人口 10,000 人を超えるのは、鳥取市・米子市・智頭町・倉 吉町の 4 市町であった。1970 年では、鳥取市・米子市・倉吉市・境港市・ 岩美町・智頭町・気高町・青谷町・東伯町・日南町の 10 市町であった。

注 28）鳥取県中学校創立四十年記念誌, p21 に「古布庄中、聖郷中統合して聖 郷中 (スクールバス県下第 1 号)」とある。また、東伯町誌 p. 384 の聖郷中 の略年には「1950 年統合。1951 年実質統合、古布庄地区生徒はスクールバ ス利用により通学。1 953 年寄宿舎新築」とある。なお、後年ではあるが県 内でも特に山間部の日南町では 1974 年に山間部のスクールバスや冬季寄 宿舎も整備された上で統合が実現している。

注 29）鳥取県教育史, p. 526, 1979 に「5 件の統合が行われた。こうして全国 に先がけていち早く着手した本県の学校統合は、現実の必要性を具現した ことにより、さらに強力に推進する段階となった」とある。
注 30）中学校分布は本校のみで分校は含まれていない。尚、図中に丸数字で 表 6 左端の数字を記入し、中学校統合状況との整合性を担保している。

注 31）昭和の町村合併後の町村域を越えた形で統合した中学校には、1953 年 に南谷村・矢送村・山守村が合併して関金町が発足したことに伴い、山守 村立山守中と組合立鴨川中を統合し、関金町倉吉市組合立鴨川中と改称し たものと、1970 年に羽合町立羽合中・泊村立泊中・北条町立北条中が統合 し、2 町 1 村の組合立北溟中となったものの 2 校がある。羽合町史では、 「1960 年ごろから生徒の減少傾向を心配し、将来の学校運営に対する心配 があるため、1967 年には隣接自治体と協議をはじめた」とある。

注 32） 1959 年の町村合併後、1960 年 2 月に町議会から町長への意見書に、 「中学校は将来一校とす心゙き(中略)、充実した校舎及び教材に (中略) 期待」 とある(日南町史, 近代政治経済二, pp. 405-412, 1984)。1974 年に山間部の スクールバスや冬季寄宿舎も整備され、586 名の統合校が発足。

注 33）文部科学省初等中等教育局「小中一貫教育等についての実態調査の結 果（2014 年 9 月）」内の小中一貫教育校舎の設置状況の分類に基づく。

注 34）山陰両県の施設一体型校舎での小中一貫校には、鳥取市立湖南学園 • 若桜町立若桜学園、松江市立八束学園（旧八束町）があり、いずれも筆者 らの調査より、少子化によって地域に小中学校校舎を存続させることを理 由に一貫校を設置している。さらに鳥取市旧福部村では幼小中一貫校の福 部未来学園が 2016 年度に名目統合し、早ければ 2018 年度から統合校舎で の運用が予定されている（朝日新聞 2016 年 4 月 21 日鳥取版 25 面参照）。

\section{参考文献}

1）安田隆子: 学校統廃合-公立小中学校に関わる諸問題-, 調査と情報 第 640 号, pp. 1-10, 2009. 4

2) 屋敷和佳 : 小. 中学校統合の進行と学校規模, 国立教育政策研究所紀要, 第 141 集, pp. 19-41, 2012.3

3）藤野哲生・藍澤宏・菅原麻衣子 : 公立小学校廃校の要因とその課題に関す る研究, 日本建築学会計画系論文集, No649, pp. 579-585, 2010.3

4) 斎尾直子: 公立小中学校の統廃合プロセスと廃校舎利活用に関する研究, 日本建築学会計画系論文集, No. 627,pp. 1001-1006, 2008. 5

5）野沢英希・谷口元・恒川和久・太幡英亮 : 廃校のある地域属性の特徴と再 利用に関する研究, 日本建築学会計画系論文集, No. 674, pp. 865-872, 2012.4

6) 山本幸子・中園眞人・清水聡士 : 廃校となった公立小中学校施設の運用状 況, 日本建築学会技術報告集, 第 18 巻 第 38 号, pp. 351-354, 2012.2

7) 中園眞人他 7 名：山口県における公立中学校の生徒・学校数の推移(1963 -2011), 日本建築学会技術報告集, 第21巻 第48号, pp. 753-758, 2015. 6

8) 細田智久他 6 名：島根県における公立中学校の生徒・学校数の推移 (1960 -2010), 日本建築学会技術報告集, 第 22 巻 第 51 号, pp. 689-694, 2016.6

9）林正巳 : 町村合併の政治地理的研究 : 第 1 報 鳥取県, 人文地理学会人文地 理 7 (4), pp. 284-293, 1955

10) 鳥取県：鳥取県史, 鳥取県教育委員会：鳥取県教育史, 鳥取県中学校校長 会 : 鳥取県中学校創立四十周年記念誌・中学校 40 年の歩夕, 県内各市町村 : 気高町誌, 鹿野町誌下巻, 大山町誌, 青谷町誌, 智頭町誌, 米子市中学校教育 史, 新修米子市史第 4 巻, 名和町誌, 岩美町誌, 東伯町誌, 国府町誌, 佐治村誌 倉吉市史 第三巻 近 - 現代編, 倉吉市誌, 新修 境港市 本文編, 境港市史下 巻, 鳥取市教育百年史, 溝口町誌, 江府町史, 日野町誌, 中山町史, 日南町史, 淀江町誌, 日吉津村誌 下巻, 岸本町誌, 会見町誌 完結編, 会見町誌 続編, 西 伯町誌, 赤崎町誌, 大栄町誌, 新修北条町史, 北条町誌, 三朝町誌, 東郷町誌, 泊村誌, 羽合町史 (後編), 用瀬町誌, 若桜町誌, 八東町誌, 八東町 45 年史, 河原町誌, 船岡町誌, 郡家町誌, 新編 八頭郡誌 3 巻 八頭郡教育のあゆみ, 福 部村誌

11）鳥取県教育委員会：鳥取県教育史, 戦後編, pp. 39-43, 1959

12）鳥取県：鳥取県史, 近代, 第 4 巻，創設期の新制中学, pp. 161-163, 1969

13）八頭郡町村会 : 新編八頭郡誌, 3 巻, 八頭郡教育のあゆみ, p. 300,1988

14）鳥取県教育委員会：鳥取県教育史, pp. 523-724, 1979

15) 鳥取県：鳥取県町村合併誌,pp. 224-330, 1964

16）牛島朗・中純一・中園眞人:山口県における明治初期の戸長区と小学区の 再編が町村合併に及ぼした影響, 日本建築学会計画系論文集, No. 726, pp. 1685-1694, 2016. 8

17) 細田智久他 6 名:鳥取県における公立小学校の児童・学校数の推移 (1960-2011)，日本建築学会技術報告集, 第 21 巻第 47 号, pp. 275-280, 2015.2 
PUBLIC JUNIOR HIGH SCHOOL FOUNDATION AND REORGANIZAITION

BY MUNICIPAL MERGER IN THE SHOWA PERIOD IN TOTTORI PREFECTURE

\author{
Tomohisa HOSODA* , Mahito NAKAZONO **, Ryota MITANI***, \\ Akira USHIJIMA**** and Reiko SHIMOKURA***** \\ * Assoc. Prof., National Institute of Technology, Yonago College, Dr. Eng. \\ * Prof., Graduate School of Sciences and Tech. for Innovation, Yamaguchi Univ., Dr. Eng. \\ *** Grad. Student, Graduate School of Science and Eng., Yamaguchi Univ. \\ **** Assist. Prof., Graduate School of Sciences and Tech. for Innovation, Yamaguchi Univ., Dr. Eng. \\ $* * * * *$ Assoc. Prof., National Institute of Technology, Kure College, Dr. Eng.
}

\title{
1. Introduction
}

After World War II, new junior high schools were established in many municipalities by the reform of the school education system. Later, at the time of implementing the municipal merger of Showa, many of these new junior high schools were consolidated.

2. Purpose

This paper addresses the reorganization process of public junior high schools in the Tottori Prefecture. This paper considers that the local government finished the consolidation of junior high schools in the first half of the 1970s and organized a new junior high establishment status that were implemented in 1947. This paper aims to clarify the relationship between the municipal merger and the consolidation of junior high schools in Showa in each municipality since 1953.

3. Conclusion

After World War II, the Tottori Prefecture had many municipalities compared to the expected number for its resident population, and many small new junior high schools were founded in 1947. In 1950, the Prefecture Board of Education established the "junior high school maintenance strengthening of the principle matters," which included the policy of establishing joint junior high schools that are shared by several small municipalities. The "junior high school maintenance strengthening promotion committee" determined and encouraged the amalgamation for 22 junior high schools. However, after enforcing the Municipal Merger Promotion Law of 1953, small-scale municipalities were themselves amalgamated as a result of a recommendation based on a merger plan encouraging prefecture governments. There was little relationship between the recommended municipal areas and the catchment area of joint junior high schools, and recommendations regarding municipal mergers were prioritized. Therefore, the "Five-Year School Reorganization Plan" of 1954 proposed the junior high school reorganization policies that were considered the future municipal mergers.

Of the 36 municipalities that negotiated the merger agreement at the time of merging of Showa, 21 municipalities promoted the amalgamation of junior high schools in the first half of the 1970s, became each town 1 junior high school. The result of the municipal merger of Showa had a major impact on the timing and scope of the reorganization of junior high schools. In particular, nine municipalities that wrote amalgamation of the future in merger agreement amalgamated junior high school of all municipalities during 1956-1964, became each town 1 junior high school. In this way, the towns and villages section became the basically format of each municipality 1 junior high school that was restructured school by the municipal merger.

At that time, the Tottori Prefectural Board of Education urged the amalgamation of different schools into one school that can be shared by more than one municipality. A consolidation of junior high schools was completed in the early stages of the 1970s. Since then, the operation of junior high schools has been stable for over 40 years. 